\title{
Effect of Phosphate Solubilizing Bacteria on Yield of Transplanted Rice under Lateritic Belt of West Bengal, India
}

\author{
Bijay Biswakarma*, Hemkalyan Verma and N.C. Sarkar \\ Department of Agronomy, Palli Siksha Bhavana, Visva-Bharati, Sriniketan, \\ West Bengal, India \\ *Corresponding author
}

\section{A B S T R A C T}

\section{Keywords \\ Transplanted rice, PSB, Growth, \\ Yield, and economics \\ Article Info \\ Accepted: \\ 26 January 2018 \\ Available Online: \\ 10 February 2018}

\begin{abstract}
A field experiment was conducted during kharif season 2014 at P.S.B. Agriculture farm, Visva-Bharati, Sriniketan West Bengal to study the effect of phosphate solubilizing bacteria on growth and productivity of transplanted rice laid out in RBD with three replications. The result revealed that at harvest, highest $(1101.11 \mathrm{~g})$ dry matter was accumulated with NPK+PSB which was statistically at par but 7.9\%, 8.6\%, 13.27\% higher than $\mathrm{NP}_{0} \mathrm{~K}, \mathrm{NP}_{0} \mathrm{~K}+\mathrm{PSB}$ and $\mathrm{NPK}$, respectively. $\mathrm{NP}_{0} \mathrm{~K}+\mathrm{PSB}$ gave the highest (442.22) number of panicle $\mathrm{m}^{-2}$ which was significantly $40.70 \%$ and $37.68 \%$ higher over $\mathrm{N}_{0} \mathrm{P}_{0} \mathrm{~K}_{0}+\mathrm{PSB}$ and $\mathrm{N}_{0} \mathrm{P}_{0} \mathrm{~K}_{0}$, respectively. NPK+PSB proved best in influencing growth and productivity, which however at par with $\mathrm{NP}_{0} \mathrm{~K}, \mathrm{NPK}, \mathrm{NP}_{0} \mathrm{~K}+\mathrm{PSB}$, and $\mathrm{NP}_{0} \mathrm{~K}+\mathrm{PSB}+\mathrm{RP}$ except $\mathrm{NP}_{0} \mathrm{~K}+\mathrm{PSB}+\mathrm{RP}$ for dry matter at harvest. NPK+PSB recorded highest (₹ 52750/-) gross returns but $\mathrm{NP}_{0} \mathrm{~K}$ resulted maximum ( $₹$ 19466/-) net returns.
\end{abstract}

\section{Introduction}

Rice is the most important crop in Asia as the main staple food and to those who depend on rice farming for their livelihoods. It is the world's leading food crop, cultivated over an area of about 166.8 mha with a production of $745.17 \mathrm{mt}$ (FAOSTAT, 2013). India is the $2^{\text {nd }}$ and largest producer of rice in the World after china. The present status of rice production in India is about $105.3 \mathrm{mt}$ with an average productivity of $2.3 \mathrm{t} \mathrm{ha}^{-1}$ (IndiaStat, 2012), and it accounts for $45 \%$ of food grain production and provides employment of about $70 \%$ of the people in the rural areas, China produces $205.01 \mathrm{mt}$ of rice from 30.39 million ha area with an average productivity of $6.72 \mathrm{t} \mathrm{ha}^{-1}$
(FAOSTAT, 2013), is more than a half total productivity of India. India's rice productivity $\left(3.6 \mathrm{t} \mathrm{ha}^{-1}\right)$ is even far below the world average $\left(4.5 \mathrm{t} \mathrm{ha}^{-1}\right)$ (FAOSTAT, 2013). Some of the important reasons for declining productivity of rice in India are poor soil fertility, imbalanced and indiscriminate use of inorganic fertilizers and that too with improper management practices. In order to achieve the desired yield potential from rice, balanced and sufficient input supply with appropriate management is a focus of research which needs an immediate attention.

Phosphorus is an essential nutrient required by rice (Yahya et al., 1989; Kim et al., 1998) and has a defined role in plant metabolisms such 
as root development, photosynthesis, nutrient transport within the plant, meiosis, phospholipid in cell walls, reproductive parts of plant (Rasipour et al., 2007; Kianirad, 1995). Phosphorus deficiency can be removed with supplying phosphate to the soils but increasing phosphorus uptake and decreasing phosphorus fixation in soils is complicated and important. Rehman (2004) showed that available phosphorus inplants was affected by three factors: plant available phosphorus concentration in soil solution, the amount of exchangeable phosphorus and the amount of relative phosphorus uptake in soils.

Use of microorganisms as environment friendly biofertilizer helps to reduce the much expensive phosphatic fertilizers. Phosphatic biofertilizer could help to increase the availability of accumulated phosphate by solubilization efficiency of biological nitrogen fixation and increase availability of $\mathrm{Fe}, \mathrm{Zn}$ etc., through production of plant growth promoting substances (Kucey et al., 1989).Trials with PSB indicated yield increases in rice (Tiwari et al., 1989), and other cereals (Afzal et al., 2005; Ozturk et al., 2003). Biological phosphate fertilizers containing beneficial bacteria and fungi increased phosphate solutions by increasing soil acidity or alkaline phosphatase enzyme, which can be absorbed by plants easily.

Soil chemical and biological characteristics improved by biofertilizer; moreover due to the use of low doses of chemical fertilizers, agricultural production will be free from contaminants (Habbasha et al., 2007; Salimpour et al., 2010). Several research groups have compared the effects of biological and chemical fertilization in the flooded rice system (Mathar et al., 1981; Khadr et al., 1985; Jeyaraman et al., 1988) and reported that biofertilization could provide a better alternative for the extensive use of phosphate fertilizer in rice production.
Chemical fertilizers are one ofthe major sources of providing phosphorus in plants, but environmental hazards caused by their overuses have led to an alarming threat. Phosphate solubilizing bacteria (PSB) are a group of beneficial bacteria capable hydrolysis of organic and inorganic phosphorus from insoluble compound. Till recent, a number of the PSB has been reported for solubilizing unavailable soil phosphorous into available form. However, Strain $\mathrm{P}_{4}$ (Burkholderia sp.) has additive advantage over the other reported that it has no antagonism i.e. it lives in coinoculation status with Trichoderma viridi, unlike other PSB. It has ability to solubilize rock phosphate, also produces siderophore (iron chelating substances) which can be used by the plant and as well as organism itself. Thus, it brings soil pathogens under iron stress condition. Moreover, $\mathrm{P}_{4}$ strain also produces growth promoting substance like IAA. Keeping the above facts in view, the present investigation entitled Effect of Phosphate Solubilizing Bacteria on growth and Productivity of transplanted rice (Oryza sativa L.) has been planned with the following objectives: -i) To study the effect of PSB on growth and productivity of transplanted rice.ii) To study the economics of rice cultivation.

\section{Materials and Methods}

A field experiment was conducted during kharif season 2014 (July to October) at Palli Siksha Bhavana Agriculture farm, VisvaBharati, Sriniketan West Bengal, the soil of the experimental plot was sandy loam in texture (Ultisol). The field is situated at about $23^{0} 39.823^{\prime} \mathrm{N}$ latitude and $87^{0} 37.972^{\prime} \mathrm{E}$ longitude with an average altitude of $60 \mathrm{~m}$ above the mean sea level. The location of experimental site is in the western part of West Bengal under sub humid red and lateritic agro-ecological zone. Normally the area received about $1000 \mathrm{~mm}$ rainfall during the kharif season (July to October). The minimum 
weekly temperature varied from $19.66^{\circ} \mathrm{C}$ in October to $27.89^{\circ} \mathrm{C}$ in July and the maximum temperature ranged from $29.90^{\circ} \mathrm{C}$ in October to $35.51^{\circ} \mathrm{C}$ in September during the cropping season. The relative humidity during cropping period varied from 79.14 to $90.0 \%$. The long term average relative humidity also varied from 74.8 to $87.0 \%$. This indicated that the relative humidity of the cropping season was almost normal of this area.

The soil of the experimental field had acidic in soil reaction of $\mathrm{pH} 5.65$ with low level of organic carbon $0.67 \%$ (Walkley and Black, 1934) and available nitrogen $157.93 \mathrm{~kg} \mathrm{ha}^{-1}$ (Subbiah and Asija, 1956), but medium level of available phosphorus (Olsen et al., 1954) and ammonium acetate exchangeable potassium (Hanway and Heidel, 1952).

\section{Experimental treatments and design}

The experiment was conducted in a completely randomize block design with three replication, consisting of seven treatment combination i.e. $\quad \mathrm{NP}_{0} \mathrm{~K}, \quad \mathrm{NP}_{0} \mathrm{~K}+\mathrm{PSB}$, $\mathrm{NP}_{0} \mathrm{~K}+\mathrm{PSB}+\mathrm{ROCK}$ PHOSPHATE, NPK, $\mathrm{NPK}+\mathrm{PSB}, \quad \mathrm{N}_{0} \mathrm{P}_{0} \mathrm{~K}_{0}+\mathrm{PSB}, \quad \mathrm{N}_{0} \mathrm{P}_{0} \mathrm{~K}_{0} . \quad$ Rice variety selected for the experiment was MTU 1010 and the species of phosphate solubilising bacteria was Burkholderia spp. strain $\mathrm{P}_{4}$.

\section{Characteristics of cultivar}

Rice variety MTU 1010 was grown to study the effect of phosphate solubilising bacteria on growth and productivity during kharif season. The variety was released by Andhra Pradesh Rice Research Institute (APRRI), which is developed by cross-breeding of Krishnaveni with IR64. The variety is widely planted variety of India as well as world. It is a Semi dwarf with medium tillering green foliage, grain straw glumed, long slender, high yielding fine grain and resistant to blast and tolerant to BPH varieties. The duration of this variety ranges from 110-115 days. The grains are White, translucent in colour and are of superior quality with $23.0-25.0 \mathrm{~g}$ of its test weight. It can produce 73-74 q grains $\mathrm{ha}^{-1}$ in kharif season under good management practices.

\section{Phosphate Solubilizing Bacteria (PSB)}

The phosphate solubilizing bacteria strain $\mathrm{P}_{4}$ was isolated from the plant rhizospheric soil (soil type-red lateritic soil of Santiniketan) It was isolated on pikovskaya's agar plates containing insoluble tricalcium phosphate (TCP)as sole P source, and was selected on the basis of solubilizing zone produced by the strain. The isolated strain can produce more than $400 \mu \mathrm{g} / \mathrm{ml}$ of soluble phosphate is PVK both (liquid medium) in the presence of TCP. It is also able to solubilize four different rock phosphates viz., Jordan rock phosphate, purulia rock phosphate, Udaipur rock phosphate, mussorie rock phosphate in appreciable amount. The isolated strain was also able to grow on nitrogen free Burk's medium which indicates its nitrogen fixing property. Though it is gram negative rod shaped bacteria it has no antagonism i.e. it release in co-inoculation status with Trichoderma viridi, unlike other Phosphate solubilizing bacteria.

\section{Land preparation and fertilizer application}

The main field was prepared by disk ploughing twice followed by puddling in standing water. The perfect leveling was done by using wet land leveler. After final land preparation, the land was left for 2 days to settle the soil. Then layout of plots was done with adequate number of bunds and channels to provide irrigation and draining channels for each treatment.

The fertilizer (urea for nitrogen, single super phosphate, rock phosphate, phosphate 
solubilising bacteria for phosphorous and murate of potash for potassium) was weighted separately as per the treatment combination. Required quantity of fertilizer was applied uniformly in the plots through broadcast method of application, PSB was inoculated with seedling's root for half an hour's as per treatments. Half dose of nitrogen as per treatments was applied in each plot before transplanting. The rest half nitrogen was top dressed in two splits- 1/4th at active tillering and remaining at panicle initiation stage. And finally one month old seedlings were transplanted in the main field on 3rd Aug. 2014 with 2-3 seedlings per hill.

\section{Studies on growth and yield attributes of rice}

In each plot, five plants were randomly chosen to calculate plant height at 30,60 and 90 DAT. The average height of these five plants was calculated for determining the average plant height in each treatment using a standard meter scale and was expressed in $\mathrm{cm}$. The number of tillers per hill was recorded at 30 , 60 and 90 DAT from randomly selected 5 hills in each plot and then number of tillers per unit area was estimated for each plot. Leaf area plant $^{-1}$ was measured by leaf area meter (LICOR Model LI3100). Based on the leaf area plant ${ }^{-1}$, the LAI was obtained by using the formula given by Johnson (1967).

\section{Leaf area plant ${ }^{-1}$ \\ $\mathrm{LAI}=$ \\ Land area occupied by individual plant}

For dry matter accumulation destructive samples were taken at 30,60, and 90 DAT from each plot. The plant were cut at the ground level and kept them separately in brown paper packet during sampling. The green leaves, stem were separated from each sample in each plot and dried in a hot oven at $60-80^{\circ} \mathrm{C}$ for 48 hours till constant weight were obtained. The dry weight of the plant (stem and leaves) for each plot was recorded with an electric digital balance for determining the dry matter accumulation $\left(\mathrm{g} / \mathrm{m}^{2}\right)$.

The selected 10 panicles, which were used for panicle length measurement, were also used to record the weight of the panicles, mean panicle weight was computed, and number of grains per panicle was counted. The 1,000filled grains, taken from sampled panicles, were first counted by and then weighed to compute the 1,000-grain weight.

\section{Yields and harvest index of rice}

Harvesting of rice was undertaken as soon as it attained the harvest maturity. The harvesting was done with sickles after leaving the border area. Net plots were demarcated at first from the portion of the plot kept for recording grain yield. Plants from the demarcated net plot area were harvested, tied in bundles and taken to the threshing floor for drying and threshing. The harvested plants were dried for 3-4 days to bring down the moisture content to around $14 \%$. The sun dried grains obtained after threshing and cleaning from the harvested area of each plot were weighed for recording grain yield in each plot. The grain yield thus obtained was then converted into $\mathrm{kg} \mathrm{ha}^{-1}$ for each plot. Straw yield was obtained by deducting the grain weight from the total weight. The economic yield (grain) per unit of biological yield i.e., grain and straw yield of the crop was determined by the following formula as suggested by Donald (1962).

$$
\text { H. I. = } \frac{\text { Economic yield }}{\text { Biological yield }} \times 100
$$

The economic yield indicates the seed yield, whereas the biological yield represents the total yield of above ground plant parts recorded in this experiment. 


\section{Statistical analysis}

All the replicated data obtained from the experiment were statistically analysed using the F-testas per the procedure given by Gomez and Gomez (1984). Least significant difference (LSD) values at $\mathrm{P}=0.05$ were used to determine the significance of differences between treatment means.

\section{Economics}

To calculate the cost of cultivation, gross return, net return and return per rupee invested of different treatments, the cost of various inputs like seeds, fertilizers, herbicides and all other inputs including labour charges were estimated as per price of the items in the local market. The value of products like grain and straw was also calculated on the basis of available price at the local market.

\section{Results and Discussion}

\section{Growth attributes}

\section{Plant height (cm)}

At 30 DAT, the maximum plant height (65.87 $\mathrm{cm})$ was recorded with $\mathrm{NP}_{0} \mathrm{~K}$ which was significantly higher than NPK, NPK+PSB, $\mathrm{N}_{0} \mathrm{P}_{0} \mathrm{~K}_{0}+\mathrm{PSB}$, and $\mathrm{N}_{0} \mathrm{P}_{0} \mathrm{~K}_{0}$. On the other hand, $\mathrm{NP}_{0} \mathrm{~K}+\mathrm{PSB}$ gave next tallest plant height $(63.07 \mathrm{~cm})$ and found statistically at par with all the treatments except $\mathrm{N}_{0} \mathrm{P}_{0} \mathrm{~K}_{0}+\mathrm{PSB}$ and $\mathrm{N}_{0} \mathrm{P}_{0} \mathrm{~K}_{0}$ (Table 1).

At 60 DAT also, tallest $(112.35 \mathrm{~cm})$ plant height was recorded from the same treatment i.e., $\mathrm{NP}_{0} \mathrm{~K}$ which was significantly higher among all the treatment except $\mathrm{NP}_{0} \mathrm{~K}+\mathrm{PSB}$. $\mathrm{NP}_{0} \mathrm{~K}+\mathrm{PSB}$ also exhibited taller $(63.07 \mathrm{~cm})$ plants significantly higher than NPK+PSB, $\mathrm{N}_{0} \mathrm{P}_{0} \mathrm{~K}_{0}+\mathrm{PSB}$ and $\mathrm{N}_{0} \mathrm{P}_{0} \mathrm{~K}_{0}$. At harvest also, maximum plant height $(112.37 \mathrm{~cm})$ was obtained from $\mathrm{NP}_{0} \mathrm{~K}$ which was significantly higher than the $\mathrm{NP}_{0} \mathrm{~K}+\mathrm{PSB}+\mathrm{RP}, \mathrm{NPK}+\mathrm{PSB}$, $\mathrm{N}_{0} \mathrm{P}_{0} \mathrm{~K}_{0}+\mathrm{PSB}, \mathrm{N}_{0} \mathrm{P}_{0} \mathrm{~K}_{0}$. Beside that $\mathrm{NP}_{0} \mathrm{~K}+\mathrm{PSB}$ gave next tallest plant height $(109.90 \mathrm{~cm})$ and found statistically at par with all the treatments except $\mathrm{N}_{0} \mathrm{P}_{0} \mathrm{~K}_{0}+\mathrm{PSB}$ and $\mathrm{N}_{0} \mathrm{P}_{0} \mathrm{~K}_{0}$.

\section{Number of tillers $\mathbf{m}^{-2}$}

The effect of treatments on total number of tillers $\mathrm{m}^{-2}$ at 30 DAT, 60 DAT and at harvest was significantly affected by all the treatments (Table 2).

At 30 DAT, highest 528.89 tiller $\mathrm{m}^{-2}$ was observed with the treatment $\mathrm{NP}_{0} \mathrm{~K}+\mathrm{PSB}$ which was statistically at par with all the treatments except $\mathrm{N}_{0} \mathrm{P}_{0} \mathrm{~K}_{0}+\mathrm{PSB}$, and $\mathrm{N}_{0} \mathrm{P}_{0} \mathrm{~K}_{0}$. NPK+PSB gave the next best results after $\mathrm{NP}_{0} \mathrm{~K}+\mathrm{PSB}$, which was significantly higher than $\mathrm{N}_{0} \mathrm{P}_{0} \mathrm{~K}_{0}+\mathrm{PSB}$, and $\mathrm{N}_{0} \mathrm{P}_{0} \mathrm{~K}_{0}$.

At 60 DAT also, $\mathrm{NP}_{0} \mathrm{~K}+\mathrm{PSB}$ recorded significantly more number (448.89) of tillers over $\mathrm{N}_{0} \mathrm{P}_{0} \mathrm{~K}_{0}+\mathrm{PSB}$, and $\mathrm{N}_{0} \mathrm{P}_{0} \mathrm{~K}_{0}$, respectively. Next best treatment NPK+PSB also resulted significantly higher (435.56) tillers $\mathrm{m}^{-2}$ than $\mathrm{N}_{0} \mathrm{P}_{0} \mathrm{~K}_{0}+\mathrm{PSB}$ and $\mathrm{N}_{0} \mathrm{P}_{0} \mathrm{~K}$, respectively.

At harvest, $\mathrm{NP}_{0} \mathrm{~K}+\mathrm{PSB}$ proved significantly better in producing tillers over $\mathrm{N}_{0} \mathrm{P}_{0} \mathrm{~K}_{0}+\mathrm{PSB}$, and $\mathrm{N}_{0} \mathrm{P}_{0} \mathrm{~K}_{0}$, respectively. Almost similar trend was observed with NPK+PSB.

\section{Leaf area index}

At 30 DAT, highest (2.11) LAI was recorded from NPK+PSB, which was statistically at par with $\mathrm{NP}_{0} \mathrm{~K}$ and $\mathrm{NPK}$, NPK+PSB is $51.18 \%$ and $49.28 \%$ significantly higher over $\mathrm{N}_{0} \mathrm{P}_{0} \mathrm{~K}_{0}$ and $\mathrm{N}_{0} \mathrm{P}_{0} \mathrm{~K}_{0}+\mathrm{PSB}$ (Table 3).

At 60 DAT also, NPK+PSB gave the highest (7.02) LAI that was significantly higher than all treatments except $\mathrm{NP}_{0} \mathrm{~K}$ (6.84), and $\mathrm{NPK}+\mathrm{PSB}$ significantly higher than rest all treatments. 
At harvest, highest (4.25) LAI was noticed from NPK+PSB, which was significantly higher over all the treatment except $\mathrm{NP}_{0} \mathrm{~K}$; beside it was $28.47 \%$ and $32.5 \%$ significantly higher over $\mathrm{N}_{0} \mathrm{P}_{0} \mathrm{~K}_{0}+\mathrm{PSB}$ and $\mathrm{N}_{0} \mathrm{P}_{0} \mathrm{~K}_{0}$.

\section{Dry matter accumulation $\left(\mathrm{g} \mathrm{m}^{-2}\right)$}

A significant response was obtained from different effect of treatments towards dry matter accumulation at 30 DAT, 60 DAT, and at harvest. At 30 DAT, The maximum (286.11 g) dry matter accumulation was noticed with treatment NPK, which was significantly higher over $\quad \mathrm{NP}_{0} \mathrm{~K}, \quad \mathrm{NP}_{0} \mathrm{~K}+\mathrm{PSB}+\mathrm{RP}$, $\mathrm{N}_{0} \mathrm{P}_{0} \mathrm{~K}_{0}+\mathrm{PSB}$, and $\mathrm{N}_{0} \mathrm{P}_{0} \mathrm{~K}_{0}$ (Table 4).

This treatment though statistically at par but recorded $15.45 \%, 23.33 \%$ higher dry matter over $\mathrm{NPK}+\mathrm{PSB}$ and $\mathrm{NP}_{0} \mathrm{~K}+\mathrm{PSB}$, respectively. On the other hand NPK+PSB statistically at par with all the treatment except $\mathrm{N}_{0} \mathrm{P}_{0} \mathrm{~K}_{0}$.

At 60 DAT, highest (935.22 g) dry matter accumulation was taken place with NPK+PSB which was significantly $22.86 \%, 26.2 \%$, and $39.13 \%$ higher than $\mathrm{N}_{0} \mathrm{P}_{0} \mathrm{~K}_{0}+\mathrm{PSB}$, $\mathrm{NP}_{0} \mathrm{~K}+\mathrm{PSB}+\mathrm{RP}$ and $\mathrm{N}_{0} \mathrm{P}_{0} \mathrm{~K}_{0}$, respectively. Next highest $(829.18$ g) dry matter was recorded highest with $\mathrm{NP}_{0} \mathrm{~K}$ that was significantly higher than $\mathrm{NP}_{0} \mathrm{~K}+\mathrm{PSB}$, $\mathrm{NP}_{0} \mathrm{~K}+\mathrm{PSB}+\mathrm{RP}, \mathrm{N}_{0} \mathrm{P}_{0} \mathrm{~K}_{0}+\mathrm{PSB}$, respectively.

At harvest, highest (1101.11 g) dry matter was accumulated with NPK+PSB which was statistically at par but $7.9 \%, 8.6 \%, 13.27 \%$ higher than $\mathrm{NP}_{0} \mathrm{~K}, \mathrm{NP}_{0} \mathrm{~K}+\mathrm{PSB}$ and $\mathrm{NPK}$, respectively.

The same treatment however, $19.7 \%, 22.89 \%$, and $33 \%$ was higher than $\mathrm{N}_{0} \mathrm{P}_{0} \mathrm{~K}_{0}+\mathrm{PSB}$, $\mathrm{NP}_{0} \mathrm{~K}+\mathrm{PSB}+\mathrm{RP}$, and $\mathrm{N}_{0} \mathrm{P}_{0} \mathrm{~K}_{0}$, respectively. $\mathrm{NP}_{0} \mathrm{~K}$ was revealed statistically at par with all the treatments except $\mathrm{N}_{0} \mathrm{P}_{0} \mathrm{~K}_{0}$ which resulted $38.5 \%$ more dry matter accumulation than $\mathrm{N}_{\mathrm{O}} \mathrm{P}_{0} \mathrm{~K}_{0}$.

\section{Yield attributing characters}

\section{Total number of panicle $\mathrm{m}^{-2}$}

The recorded data revealed that total number of panicle $\mathrm{m}^{-2}$ are significantly influenced by the treatments, $\mathrm{NP}_{0} \mathrm{~K}+\mathrm{PSB}$ gave the highest (442.22) number of panicle $\mathrm{m}^{-2}$ which was significantly $40.70 \%$ and $37.68 \%$ higher over $\mathrm{N}_{0} \mathrm{P}_{0} \mathrm{~K}_{0}+\mathrm{PSB}$ and $\mathrm{N}_{0} \mathrm{P}_{0} \mathrm{~K}_{0}$, respectively. This treatment was statistically at par with rest of the treatments. On the other hand, NPK+PSB also gave highest (426.67) number of panicle $\mathrm{m}^{-2}$ next to $\mathrm{NP}_{0} \mathrm{~K}+\mathrm{PSB}$, that was significantly higher than $\mathrm{NP}_{0} \mathrm{~K}+\mathrm{PSB}$ and $\mathrm{N}_{0} \mathrm{P}_{0} \mathrm{~K}_{0}$ (Table 5).

\section{Total number of grain panicle ${ }^{-1}$}

There was no significant difference between the treatments on this yield attributing character.

However, the maximum number of grain (130.93) was counted in (NPK) which is followed by NPK+PSB 129.80.

\section{Number of filled grain panicle ${ }^{-1}$}

The data pertaining to the effect of treatment on the number of filled grain panicle ${ }^{-1}$ found no significant differences.

However, NPK gave the maximum (109.13) number of filled grain panicle ${ }^{-1}$ followed by the treatment $\mathrm{NP}_{0} \mathrm{~K}$ and $\mathrm{NPK}+\mathrm{PSB}$ i.e.107.7 and 105.73.

\section{Panicle length (cm)}

The panicle length of rice was significantly influenced by the treatment. It revealed that the highest panicle length $(25.46 \mathrm{~cm})$ was noticed from NPK and NPK+PSB, which were statistically at par with all the treatments except $\mathrm{N}_{0} \mathrm{P}_{0} \mathrm{~K}_{0}+\mathrm{PSB}$, and $\mathrm{N}_{0} \mathrm{P}_{0} \mathrm{~K}_{0}$. 


\begin{tabular}{|c|c|c|c|}
\hline \multirow[t]{2}{*}{ Treatments } & \multicolumn{3}{|c|}{ Plant height $(\mathrm{cm})$} \\
\hline & $30 \mathrm{DAT}$ & $60 \mathrm{DAT}$ & Harvest \\
\hline $\mathbf{N P}_{0} \mathrm{~K}$ & 65.87 & 112.35 & 112.37 \\
\hline $\mathrm{NP}_{0} \mathrm{~K}+\mathrm{PSB}$ & 63.07 & 110.27 & 109.90 \\
\hline $\mathrm{NP}_{0} \mathrm{~K}+\mathrm{PSB}+\mathrm{RP}$ & 62.99 & 106.59 & 106.75 \\
\hline NPK & 59.85 & 107.65 & 107.91 \\
\hline NPK + PSB & 60.54 & 105.61 & 105.89 \\
\hline $\mathbf{N}_{0} \mathbf{P}_{0} \mathbf{K}_{0}+\mathbf{P S B}$ & 54.83 & 96.41 & 96.13 \\
\hline $\mathbf{N}_{0} \mathbf{P}_{0} \mathbf{K}_{0}$ & 53.60 & 95.66 & 96.37 \\
\hline SEm \pm & 1.497 & 1.329 & 1.728 \\
\hline CD $(p=0.05)$ & 4.613 & 4.096 & 5.325 \\
\hline CV $(p=0.05)$ & 4.314 & 2.194 & 2.849 \\
\hline
\end{tabular}

\section{Table.2 Effect of treatments on tillers $\mathrm{m}^{-2}$}

\begin{tabular}{l|} 
Treatments \\
\hline $\mathrm{NP}_{0} \mathrm{~K}$ \\
\hline $\mathrm{NP}_{0} \mathrm{~K}+\mathrm{PSB}$ \\
\hline $\mathrm{NP}_{0} \mathrm{~K}+\mathrm{PSB}+\mathrm{RP}$ \\
\hline $\mathrm{NPK}$ \\
\hline $\mathrm{NPK}+\mathrm{PSB}$ \\
\hline $\mathrm{N}_{0} \mathbf{P}_{0} \mathbf{K}_{0}+\mathrm{PSB}$ \\
\hline $\mathbf{N}_{0} \mathbf{P}_{0} \mathbf{K}_{0}$ \\
\hline $\mathrm{SE} m \pm$ \\
\hline $\mathrm{CD}(p=0.05)$ \\
\hline $\mathrm{CV}(p=0.05)$ \\
\hline
\end{tabular}

\begin{tabular}{|c|c|c|}
\hline Tillers $\mathrm{m}^{-2}$ & & \\
\hline $30 \mathrm{DAT}$ & $60 \mathrm{DAT}$ & Harvest \\
\hline 464.44 & 364.44 & 362.22 \\
\hline 528.89 & 448.89 & 442.22 \\
\hline 502.22 & 404.44 & 404.44 \\
\hline 453.33 & 368.89 & 366.67 \\
\hline 524.44 & 435.56 & 426.67 \\
\hline 326.67 & 266.67 & 262.22 \\
\hline 362.22 & 300 & 275.56 \\
\hline 42.156 & 28.004 & 26.136 \\
\hline 129.89 & 86.290 & 80.535 \\
\hline 16.163 & 13.115 & 12.476 \\
\hline
\end{tabular}

\section{Table. 3 Effect of treatments on leaf area index}

\begin{tabular}{l|} 
Treatments \\
\hline $\mathrm{NP}_{0} \mathrm{~K}$ \\
\hline $\mathrm{NP}_{0} \mathrm{~K}+\mathrm{PSB}$ \\
\hline $\mathrm{NP} \mathrm{P}_{0} \mathrm{~K}+\mathrm{PSB}+\mathrm{RP}$ \\
\hline $\mathrm{NPK}$ \\
\hline $\mathrm{NPK}+\mathrm{PSB}$ \\
\hline $\mathrm{N}_{0} \mathrm{P}_{0} \mathbf{K}_{0}+\mathrm{PSB}$ \\
\hline $\mathrm{N}_{0} \mathrm{P}_{0} \mathbf{K}_{0}$ \\
\hline $\mathrm{SEm} \pm$ \\
\hline $\mathrm{CD}(p=0.05)$ \\
\hline $\mathrm{CV}(p=0.05)$ \\
\hline
\end{tabular}

\begin{tabular}{|c|c|c|}
\hline Leaf area index & \multicolumn{3}{|c|}{} \\
\hline 30 DAT & 60 DAT & Harvest \\
\hline 2.00 & 6.84 & 4.07 \\
\hline 1.85 & 6.57 & 3.75 \\
\hline 1.63 & 6.56 & 3.45 \\
\hline 1.96 & 6.70 & 3.87 \\
\hline 2.11 & 7.02 & 4.25 \\
\hline 1.07 & 5.23 & 3.04 \\
\hline 1.03 & 5.01 & 2.87 \\
\hline 0.037 & 0.060 & 0.060 \\
\hline 0.114 & 0.186 & 0.184 \\
\hline 3.864 & 1.66 & 2.876 \\
\hline
\end{tabular}




\begin{tabular}{|c|c|c|c|}
\hline \multicolumn{4}{|c|}{ Table.4 Effect of treatments on dry matter accumulation } \\
\hline \multirow[t]{2}{*}{ Treatments detail } & \multicolumn{3}{|c|}{ Dry wt. (gram m ${ }^{-2}$ ) } \\
\hline & 30 DAT & $60 \mathrm{DAT}$ & Harvest \\
\hline $\mathbf{N P}_{0} \mathrm{~K}$ & 203.61 & 829.18 & 930.60 \\
\hline $\mathbf{N P} \mathbf{K}+\mathbf{P S B}$ & 219.34 & 825.33 & 923.56 \\
\hline $\mathbf{N P}_{0} \mathrm{~K}+\mathrm{PSB}+\mathrm{RP}$ & 207.35 & 689.59 & 779.57 \\
\hline NPK & 286.11 & 786.83 & 876.81 \\
\hline NPK + PSB & 241.89 & 935.22 & 1011.01 \\
\hline $\mathbf{N}_{0} \mathbf{P}_{0} \mathbf{K}_{0}+\mathbf{P S B}$ & 188.43 & 721.49 & 811.47 \\
\hline $\mathbf{N}_{0} \mathbf{P}_{0} \mathbf{K}_{0}$ & 125.62 & 569.25 & 671.44 \\
\hline SEm \pm & 23.226 & 58.652 & 57.297 \\
\hline $\mathrm{CD}(p=0.05)$ & 71.56 & 180.726 & 176.551 \\
\hline CV $(p=0.05)$ & 19.126 & 13.274 & 11.569 \\
\hline
\end{tabular}

\section{Table.5 Effect of treatments on yield attributing characters}

\begin{tabular}{|c|c|c|c|c|c|}
\hline Treatments & $\begin{array}{l}\text { Number } \\
\text { of panicle } \\
\mathrm{m}^{-2}\end{array}$ & $\begin{array}{l}\text { Total number } \\
\text { of grain } \\
\text { panicle }^{-1}\end{array}$ & $\begin{array}{l}\text { Number of } \\
\text { filled grain } \\
\text { panicle }^{-1}\end{array}$ & $\begin{array}{l}\text { Panicle } \\
\text { length }(\mathrm{cm})\end{array}$ & $\begin{array}{l}\text { Test wt. } \\
\text { (g) }\end{array}$ \\
\hline $\mathbf{N P}_{\mathbf{0}} \mathbf{K}$ & 362.22 & 127.53 & 107.07 & 24.90 & 23.78 \\
\hline $\mathbf{N P}_{0} \mathbf{K}+\mathbf{P S B}$ & 442.22 & 120.47 & 99.33 & 25.27 & 23.75 \\
\hline $\mathrm{NP}_{0} \mathrm{~K}+\mathrm{PSB}+\mathrm{RP}$ & 404.44 & 118.33 & 99.53 & 25.06 & 24.34 \\
\hline NPK & 366.67 & 130.93 & 109.13 & 25.46 & 25.87 \\
\hline NPK+PSB & 426.67 & 129.80 & 105.73 & 25.46 & 23.88 \\
\hline $\mathbf{N}_{0} P_{0} K_{0}+P S B$ & 262.22 & 107.60 & 91.47 & 22.63 & 24.66 \\
\hline $\mathbf{N}_{0} \mathbf{P}_{0} \mathbf{K}_{0}$ & 275.56 & 93 & 78.53 & 21.86 & 24.15 \\
\hline SEm \pm & 26.136 & 8.709 & 7.614 & 0.694 & 0.660 \\
\hline $\mathrm{CD}(p=0.05)$ & 80.53 & NS & NS & 2.14 & NS \\
\hline CV $(p=0.05)$ & 12.476 & 12.75 & 13.365 & 4.93 & 4.700 \\
\hline
\end{tabular}

\section{Table.6 Effect of treatments on biological yield and harvest index}

\begin{tabular}{|c|c|c|c|}
\hline Treatments & Grain yield kg ha-1 & Straw yield kg ${ }^{\text {ha-1 }}$ & Harvest index \\
\hline $\mathbf{N P K}$ & 4166.67 & 5353.33 & 0.44 \\
\hline $\mathrm{NP}_{0} \mathrm{~K}+\mathrm{PSB}$ & 4106.67 & 5896.67 & 0.41 \\
\hline $\mathrm{NP}_{0} \mathrm{~K}+\mathrm{PSB}+\mathrm{RP}$ & 4036.67 & 6670.00 & 0.39 \\
\hline NPK & 4143.33 & 6633.33 & 0.39 \\
\hline NPK+PSB & 4226.6 & 6256.67 & 0.41 \\
\hline $\mathbf{N}_{0} \mathbf{P}_{0} \mathrm{~K}_{0}+\mathrm{PSB}$ & 2963.33 & 3058.33 & 0.51 \\
\hline $\mathbf{N}_{0} \mathbf{P}_{0} \mathbf{K}_{0}$ & 2686.67 & 3103.33 & 0.46 \\
\hline SEm \pm & 168.646 & 695.717 & 0.035 \\
\hline CD $(p=0.05)$ & 519.65 & 2143.72 & NS \\
\hline$C V(p=0.05)$ & 7.765 & 22.815 & 14.24 \\
\hline
\end{tabular}




\begin{tabular}{|c|c|c|}
\hline Treatments & Gross return $\left(₹ \mathrm{ha}^{-1}\right)$ & Net return $\left(₹ \mathrm{ha}^{-1}\right)$ \\
\hline $\mathbf{N P}_{\mathbf{0}} \mathrm{K}$ & 51186.67 & 19466.67 \\
\hline $\mathbf{N P}_{0} \mathbf{K}+\mathbf{P S B}$ & 51070.00 & 19300.00 \\
\hline $\mathbf{N P}_{0} \mathrm{~K}+\mathrm{PSB}+\mathrm{RP}$ & 51073.33 & 18053.33 \\
\hline NPK & 52210.00 & 18090.00 \\
\hline NPK + PSB & 52750.00 & 18580.00 \\
\hline $\mathbf{N}_{0} \mathbf{P}_{0} \mathbf{K}_{0}+\mathbf{P S B}$ & 35655.00 & 6095.00 \\
\hline $\mathbf{N}_{0} \mathbf{P}_{0} \mathbf{K}$ & 32656 & 3146.67 \\
\hline SEm \pm & 2055.119 & 2055.119 \\
\hline $\mathrm{CD}(p=0.05)$ & 6332 & 6332.451 \\
\hline CV $(p=0.05)$ & 7.629 & 24.254 \\
\hline
\end{tabular}

\section{Test weight}

No significant response was found from the effect of treatments on test weight However highest $(25.87 \mathrm{~g})$ test weight was recorded with NPK, followed by $\mathrm{N}_{0} \mathrm{P}_{0} \mathrm{~K}_{0}+\mathrm{PSB}$.

\section{Biological yield}

\section{Grain yield}

The highest grain yield $\left(4226.6 \mathrm{~kg} \mathrm{ha}^{-1}\right)$ was recorded with treatment NPK+PSB which is significantly higher $(29.88 \%)$ than $\mathrm{N}_{0} \mathrm{P}_{0} \mathrm{~K}_{0}+\mathrm{PSB}, 36.43 \%$ higher than $\mathrm{N}_{0} \mathrm{P}_{0} \mathrm{~K}_{0}$, respectively (Table 6).

$\mathrm{NP}_{0} \mathrm{~K}$ proved best after $\mathrm{NPK}+\mathrm{PSB}$ which proved significantly higher $28.8 \%$ $\mathrm{N}_{0} \mathrm{P}_{0} \mathrm{~K}_{0}+\mathrm{PSB}$ and $36.9 \%$ with $\mathrm{N}_{0} \mathrm{P}_{0} \mathrm{~K}_{0}$.

\section{Straw yield}

The maximum straw yield $\left(6670 \mathrm{~kg} \mathrm{ha}^{-1}\right)$ was recorded from $\mathrm{NP}_{0} \mathrm{~K}+\mathrm{PSB}+\mathrm{RP}$. This treatment was significantly $54.14 \%$ and $53.47 \%$ higher over the $\mathrm{N}_{0} \mathrm{P}_{0} \mathrm{~K}_{0}+\mathrm{PSB}$ and $\mathrm{N}_{0} \mathrm{P}_{0} \mathrm{~K}_{0}$, respectively; and statistically at par with all the rest of the treatments. NPK resulted $\left(6633.33 \mathrm{~kg} \mathrm{ha}^{-1}\right)$ which was significantly $53.91 \%$ and $53.21 \%$ higher over $\mathrm{N}_{0} \mathrm{P}_{0} \mathrm{~K}_{0}+\mathrm{PSB}$ and $\mathrm{N}_{0} \mathrm{P}_{0} \mathrm{~K}_{0}$, respectively.

\section{Gross returns and net returns}

It indicates that gross returns and net returns are significantly influenced by the treatments. $\mathrm{NPK}+\mathrm{PSB}$ resulted the highest gross returns (₹ 52750/-) which was significantly $32.4 \%$ and $38.09 \%$ higher over $\mathrm{N}_{0} \mathrm{P}_{0} \mathrm{~K}_{0}+\mathrm{PSB}$, and $\mathrm{N}_{0} \mathrm{P}_{0} \mathrm{~K}_{0}$, respectively. However, highest net return (₹ 19466/-) was recorded from $\mathrm{NP}_{0} \mathrm{~K}$ which was $68 \%$ and 83.8 higher over $\mathrm{N}_{0} \mathrm{P}_{0} \mathrm{~K}_{0}+\mathrm{PSB}$, and $\mathrm{N}_{0} \mathrm{P}_{0} \mathrm{~K}_{0}$ (Table 7).

At 30 DAT, the maximum plant height (65.87 cm) was recorded with $\mathrm{NP}_{0} \mathrm{~K}$ which was significantly higher than NPK, NPK+PSB, $\mathrm{N}_{0} \mathrm{P}_{0} \mathrm{~K}_{0}+\mathrm{PSB}$, and $\mathrm{N}_{0} \mathrm{P}_{0} \mathrm{~K}_{0}$. At 60 DAT also, tallest $(112.35 \mathrm{~cm})$ plant height was recorded from the same treatment but at par with only $\mathrm{NP}_{0} \mathrm{~K}+\mathrm{PSB}$. At harvest also, maximum plant height $(112.37 \mathrm{~cm})$ was obtained from NP0K which was significantly higher than the $\mathrm{NP}_{0} \mathrm{~K}+\mathrm{PSB}+\mathrm{RP}, \quad \mathrm{NPK}+\mathrm{PSB}, \quad \mathrm{N}_{0} \mathrm{P}_{0} \mathrm{~K}_{0}+\mathrm{PSB}$, $\mathrm{N}_{0} \mathrm{P}_{0} \mathrm{~K}_{0}$. This might be due to $\mathrm{P}$ availability increased in the flooded soil because of the reduction of ferric phosphate to more soluble ferrous form and hydrolysis of phosphate compound. These findings were in accordance with Fageria and Baligar, 2001 and Fageria et al., (2007).

At 30 DAT, highest 528.89 tiller $\mathrm{m}-2$ was observed with the treatment $\mathrm{NP}_{0} \mathrm{~K}+\mathrm{PSB}$. 
NPK+PSB gave the next best results after $\mathrm{NP}_{0} \mathrm{~K}+\mathrm{PSB}$. At 60 DAT also, $\mathrm{NP}_{0} \mathrm{~K}+\mathrm{PSB}$ recorded significantly more number (448.89) of tillers over $\mathrm{N}_{0} \mathrm{P}_{0} \mathrm{~K}_{0}+\mathrm{PSB}$. At harvest, $\mathrm{NP}_{0} \mathrm{~K}+\mathrm{PSB}$ again proved significantly better in producing tillers over $\mathrm{N}_{0} \mathrm{P}_{0} \mathrm{~K}_{0}+\mathrm{PSB}$, and $\mathrm{N}_{0} \mathrm{P}_{0} \mathrm{~K}_{0}$, respectively. Almost similar trend was observed with NPK+PSB. This might be due to the positive effect of PSB inoculation which results higher amount of soluble $P$ uptake in soil solution increased $\mathrm{P}$ uptake in plant, and resulted higher plant biomass and positive effect on plant growth attributes. This line was with the findings of (Panhwar et al., 2011; Ravikumar et al., 2013; Singh and Sirvastava, 2010).

At 30 DAT, highest (2.11) LAI was recorded from NPK+PSB. At $60 \mathrm{DAT}$ also NPK+PSB gave the highest (7.02) LAI that was significantly higher than all treatments except $\mathrm{NP}_{0} \mathrm{~K}$ (6.84) and At harvest, highest (4.25) LAI was noticed from NPK+PSB, which was significantly higher over all the treatment except $\mathrm{NP}_{0} \mathrm{~K}$. The LAI was found to increase from $30 \mathrm{DAT}$, to $60 \mathrm{DAT}$, followed by decreased at harvest. The increase in leaves as well as tiller bearing habit helped to increase LAI, from 30-60 DAT. However due to death in older leaves as well as ineffective tillers in the subsequent stage, LAI had been found to decrease. This might be due to more availability of nutrients because PSB inoculation significantly increased leaf chlorophyll $\beta$-carotenoid, increased $\mathrm{N}, \mathrm{P}, \mathrm{K}$ and increased content of organic acids from the soil. Burkholderia spp. also produce siderophore iron chelating substances which results more availability of micro nutrients like Fe. These findings were in accordance with (Panhwar et al., 2011; Hossian et al., 2008; Ravikumar et al., 2013; Tamgale, 2006).

At 30 DAT, The maximum (286.11 g) dry matter accumulation was noticed with treatment NPK. At 60 DAT, highest (935.22 g) dry matter accumulation was taken place with NPK+PSB which was significantly $22.86 \%, 26.2 \%$, and $39.13 \%$ higher than $\mathrm{N}_{0} \mathrm{P}_{0} \mathrm{~K}_{0}+\mathrm{PSB}, \mathrm{NP}_{0} \mathrm{~K}+\mathrm{PSB}+\mathrm{RP}$ and $\mathrm{N}_{0} \mathrm{P}_{0} \mathrm{~K}_{0}$, respectively. At harvest, highest $(1101.11 \mathrm{~g})$ dry matter was accumulated with NPK+PSB which was statistically at par but $7.9 \%, 8.6 \%$, $13.27 \%$ higher than $\mathrm{NP}_{0} \mathrm{~K}, \mathrm{NP}_{0} \mathrm{~K}+\mathrm{PSB}$ and NPK, respectively. Investigation done by Banerjee et al., 2009; Panhwar et al., 2011; Ravikumar et al., 2013; Tamgale; 2006 found that inoculation of PSB not only increased availability of NPK but also enhance micronutrients availability. However, Burkholderia spp. produce siderophore iron chelating substances which result positive effect on dry matter accumulation.

In case of yield attributing character it is noticed that, most of the character are not found significantly influenced by the treatments except number of panicle $\mathrm{m}^{-2}$ and Panicle length $(\mathrm{cm})$. But however, inoculation of PSB with other inorganic nutrients positively influenced the yield attributing characters as it solubilize nutrients and make more available to plants (Alam et al., 2008; Panhwar et al., 2013; Sapsirisopa et al., 2009; Ferreira et al., 2012; Banerjee et al., 2009; Hossain et al., 2008;).

The highest grain yield (4226.6 kg ha ${ }^{-1}$ ) was recorded with treatment $\mathrm{NPK}+\mathrm{PSB}$ which is significantly higher $(29.88 \%)$ than $\mathrm{N}_{0} \mathrm{P}_{0} \mathrm{~K}_{0}+\mathrm{PSB}$, $36.43 \%$ higher than $\mathrm{N}_{0} \mathrm{P}_{0} \mathrm{~K}_{0}$, respectively. $\mathrm{NP}_{0} \mathrm{~K}$ proved best after $\mathrm{NPK}+\mathrm{PSB}$ which proved significantly higher $28.8 \% \quad \mathrm{~N}_{0} \mathrm{P}_{0} \mathrm{~K}_{0}+\mathrm{PSB}$ and $36.9 \%$ with $\mathrm{N}_{0} \mathrm{P}_{0} \mathrm{~K}_{0}$. Singh and Sirvastawa (2010) found application of PSB along with full dose of NPK fertilizer is necessary to increased yield. PSB increased grain protein by $5-7 \%$ which resulted higher grain yield (Kar et al., 2009; Tripathy et al., 2009). Sharma et al., (2003) reported that application of PSB along with 
$35 \mathrm{~kg}$ P fertilizer increased grain yield by 10 17\%. Estrada et al., (2013) found inoculation of Herbaspirillum strain and Burkholderia spp. increased rice grain yield from $33-47 \%$ with TCP and $18-44 \%$ with TSS, respectively.

The result revealed that use of PSB performed statistically at par with the treatments where phosphorus was not applied, this revealed the supply of native soil phosphorus to the plant. In flooded soil, availability of $\mathrm{P}$ increased because of the reduction of ferric phosphate to more soluble ferrous forms and the hydrolysis of phosphate compound (Fageria and Baligar, 2001; and Fageria, 2007).

The maximum straw yield (6670 kg ha-1) was recorded from $\mathrm{NP}_{0} \mathrm{~K}+\mathrm{PSB}+\mathrm{RP}$.

This treatment was significantly $54.14 \%$ and $53.47 \%$ higher over the $\mathrm{N}_{0} \mathrm{P}_{0} \mathrm{~K}_{0}+\mathrm{PSB}$ and $\mathrm{N}_{0} \mathrm{P}_{0} \mathrm{~K}_{0}$, respectively; Banerjee et al., 2009 reported that application of PSB along with rock phosphate increased straw yield of kharif rice.

NPK+PSB resulted the highest gross returns (₹ 52750/-) which was significantly $32.4 \%$ and $38.09 \%$ higher over $\mathrm{N}_{0} \mathrm{P}_{0} \mathrm{~K}_{0}+\mathrm{PSB}$, and $\mathrm{N}_{0} \mathrm{P}_{0} \mathrm{~K}_{0}$, respectively. However, highest net return (₹ 19466/-) was recorded from $\mathrm{NP}_{0} \mathrm{~K}$ which was $68 \%$ and 83.8 higher over $\mathrm{N}_{0} \mathrm{P}_{0} \mathrm{~K}_{0}+\mathrm{PSB}$, and $\mathrm{N}_{0} \mathrm{P}_{0} \mathrm{~K}_{0}$. Yadav et al., (2008, 2009, 2013) and Kaushik et al., 2004 revealed that application of PSB along with organic source of nutrients as well as inorganic source of nutrients gave highest gross monetary returns.

NPK + PSB proved best in influencing growth and productivity, which however at par with $\mathrm{NP}_{0} \mathrm{~K}, \quad \mathrm{NPK}, \quad \mathrm{NP}_{0} \mathrm{~K}+\mathrm{PSB}, \quad$ and $\mathrm{NP}_{0} \mathrm{~K}+\mathrm{PSB}+\mathrm{RP}$ except $\mathrm{NP}_{0} \mathrm{~K}+\mathrm{PSB}+\mathrm{RP}$ for dry matter at harvest. NPK+PSB recorded highest gross returns but $\mathrm{NP}_{0} \mathrm{~K}$ resulted maximum net returns.

\section{References}

Afzal, A., S. M. Ashraf, A. Asad, M. Farooq. 2005. Effect of Phosphate Solubilizing Microorganisms on Phosphorus Uptake, Yield and Yield Traits of Wheat (Triticum aestivum L.) In Rainfed Area. International Journal of Agriculture and Biology. 2(3): 237-238.

Alam, M. S., N. M. Talukder, M. T.Islam, A. Sarkar, M. M. Hossain. 2008. Phosphate solubilizing rhizoplane bacteria on growth and yield of transplant aman rice. Journal of Agroforesty and Environment. 2(1): 1-6.

Banerjee, K., B. R. Pramanik. 2009. Effect of different doses and sources of phosphorus and phosphate solubilizing bacteria on the growth and yield of kharif rice. Research on Crops. 10(3): 489-491.

Estrada, German, Andres., Baldani, Vera., Lucia. Divan., Oliveira, Danilo, Messias, De., Urquiaga, segundo., Baldani, Jose, Ivo. 2013. Selection of phosphate-solubilizing diazotrophic Herbaspirillum and Burkholderia strains and their effect on rice crop yield and nutrient uptake. Plant Soil369:115-129.

Fageria, N. K., A. B. Santos, and V. A. Cutrim. 2007. Yield and nitrogen use efficiency of lowland rice genotypes as influenced by nitrogen fertilization. Pesquisa Agropecuaria Brasileira 42: 1029-1034.

Fageria, N. K., and V. C. Baligar. 2001. Lowland rice response to nitrogen fertilization. Communication Soil Science and Plant Analysis 32:1405-1429.

Ferreira, R. F. de., I. C. M. Cardoso, C. F. da. Silva, E. L. Souchie, M.A. C. Carneiro. 2009. Rice response to inoculation with Psolubilizing microorganisms from Brazilian Cerrado. Bioscience Journal. 25(5): 1-7.

Gomez, K. A., and A. A. Gomez. 1984. Statistical procedures for agricultural research. Second Edition, An International Rice Research Institute Book, Wiley-Inter-Science Publication, John Wiley \& Sons, New York.

Habbasha, S. F., M. Hozayn, M. A. Khalafallah. 2007. Integration effect between phosphorus levels and bio-fertilizers on quality and quantity yield of faba bean (1.) 
in newly cultivated sandy soils. Research Journal of Agriculture and Biological Sciences 3(6): 966-971.

Hanway, J. J., and H. Heidel. 1952. Soil analysis methods as used in Iowa State College Soil Testing Laboratory, Bulletin 57. Iowa State College of Agriculture, USA, pp. 131.

Hossain, M. M., M. S. Alam, N. M. Talukder, M. A. H. Chowdhury, A. Sarkar. 2008. Effect of phosphate solubilizing bacteria and different phosphatic fertilizers on nutrient content of rice. Journalof Agroforesty and Environment. 2(1): 1-6.

Jeyaraman, S., S. Purushothaman. 1988. Biofertilizer efficiency in lowland rice. International Rice Research News Letter. 13:24-26.

Kar, M., B. Hota, C. R. Sahoo. 2005. Biofertilizers in sparing applied nutrient needs of rice: its effect on nutrient acquisition, grain yield and grain quality. Journal of Plant Biology. 32(3): 217-220.

Kaushik, B. D., B. N. Mishra, R. C. Gautam, A. K. Rana. 2004. P nutrition in rice wheat cropping system with microbial consortia. Annals of Agricultural Research. 25(2): 179-186.

Khadr M. S., M. N. Baker, A. M. El-Sayed. 1985. Evaluation of some local isolates of BGA as nitrogen sources for rice. Agriculture Research. 63:209-213.

Kianirad, M. 1995. Evaluation of phosphate solubilizing microorganisms and their effect on reducing the consumption of phosphate fertilizers on soybean crops. Thesis, Tehran University Faculty of Agriculture, 117.

Kim, K.Y., D. Jordan, G. A. Mc. Donald. 1998. Enterobacter agglomerans, phosphate solubilizing bacteria and microbial activity in soil: effect of carbon sources. Soil Biology and Biochemistry. 89: 995-1003.

Kucey, R. M. N., H. H. Janzen, M. E. Leggett. 1989. Microbially mediated increases in plant-available phosphorus. Advances in Agronomy. 42: 199-228.

Mathar, S., S. Krishnamoorthy, P. Anavaraham. 1981. Azolla influenced on rice. International Rice Research News Letter. 6, 23.

Olsen, S. R., C. V. Cole, F. S. Watanabe, and L.
Dean. 1954. Estimation of available phosphorus in soil by extraction with sodium carbonate. USDA, Washington, Conc 933.

Ozturk, A. O., F. Sahin. 2003. Yield response of wheat and barley to inoculation of plant growth promoting rhizobacteria at various levels of nitrogen fertilization. Journal of Plant Nutrition and Soil Science.66:1-5.

Panhwar, Q. A., J. Shamshuddin, U. A. Naher, O. Radziah, Razi, I. M. 2013.Application of Potential Phosphate Solubilizing Bacteria and Organic Acids on Phosphate Solubilization from Phosphate Rock in Aerobic Rice. The Scientific World Journal. 272:409-10.

Panhwar, Q. A., O.Radziah, A. R. Zaharah, Sariah, M. Razi, I.M. 2011. Role of phosphate solubilizing bacteria on rock phosphate solubility and growth of aerobic rice. Journal of Environmental Biology. (32): 607-612.

Panhwar, Q. A., O.Radziah, A. Z. Rahman, Sariah, M.Razi, I. M., U. A. Naher. 2011. Contribution of phosphate solubilizing bacteria in phosphorus bioavailability and growth enhancement of aerobic rice. Spanish Journal of Agricultural Research. 9(3): 810-820.

Rasipour, L., N. A.Asgharzadeh. 2007. The interaction between the PSB and Bradirhizobium japanicum growth factors, tumor size and uptake of some nutrients in soybean. Agricultural and Natural Resource Sciences. 11(5): 40-63.

Ravikumar, S., S. Shanthy, A. Kalaiarasi, S. Sumaya. 2013. Halophilic phosphobacteria for raising vigorous growth improvement in Rice (Oryza sativa). African Journal of Agricultural Research. 8(18): 1872-1876.

Rehman, U. R. 2004. Plant availability of native, residual and fertilizer phosphorus in alluvial soils of rice tract. Doctoral dissertation, University of Agriculture Faisalabad, Pakistan.

Salimpour, S., K. Khavazi, H. Nadian, H. Besharati, M. Miransari. 2010. Enhancing phosphorous availability to canola (Brassica napus L.) using $\mathrm{P}$ solubilizing and sulfur oxidizing bacteria. Australian Journal of Crop Science. 4(5): 330-333. 
Sapsirisopa, S., K. Chookietwattana, K. Maneewan, P. Khaengkhan. 2009. Effect of salt-tolerant Bacillus inoculum on rice KDML 105 cultivated in saline soil. Asian Journal of Food and Agro Industry. (2): 6974.

Sharma, S. N., R. Prasad, Y. S. Shivay, M. K. Dwivedi, S. Kumar, D. Kumar. 2009. Effect of rates and sources of phosphorus on productivity and economics of rice (Oryza sativa) as influenced by crop residue incorporation. Indian Journal of Agronomy. 54(1): 42-46.

Sharma, S. N., R. Prasad. 2003. Yield and P uptake by rice and wheat grown in a sequence as influenced by phosphate fertilization with diammonium phosphate and Mussoorie rock phosphate with or without crop residues and phosphate solubilizing bacteria. Journal of Agricultural Science. (141): 359-369.

Singh, A. K., O. P. Sirvastawa. 2010. Effect of phosphate solubilizers and aerobic diazotrophic bacterial isolates on paddy (Oryza sativa L.). Environment and Ecology. 28(3A): 1858-1862.

Subbiah, B. V., and G. L. Asija. 1956 A rapid procedure for assessment of available nitrogen in rice soils. Current Science 25: 259-260.

Tamgale, S.D., P. A. Sarangamath, V. P. Savalagi, H. M. Manjunathaiah. 2006. Integrated use of rock phosphate as a source of phosphorus on growth and yield of upland paddy (Oryza Sativa L.). Karnataka Journal of Agricultural Sciences. 19(4): 804-809.

Tiwari, V. N., L. K. Lehri, A. N. Pathak. 1989.
Effect of inoculating crops with phosphomicrobes. Experimental Agriculture. (25):47-50.

Tripathy, P.S., M. Kar, C. R. Sahoo. 2009. Biofertilizers on nutrient acquisition, grain yield and grain quality of rice. Environment and Ecology. 27(4A): 1694-1697.

Walkley, A. J., and I. A. Black. 1934. An examination of the Degtjareff method for determination of soil organic matter and a proposed modification of the chronic acid titration method. Soil Science 37: 29-38.

Yadav, O. M., V. V. Dahiphale, G. V. Godhawale. 2008. Effect of integrated nutrient management on production and economic efficiency of rice (Oryza sativa L.) under upland drilled condition. Indian Journal of Dryland Agricultural Research and Development. 23(1): 13-18.

Yadav, S. K., V. Kumar, V. Yadav. 2009. Effect of organic farming on productivity, soil health and economics of rice (Oryza sativa)-wheat (Triticum aestivum) system. Indian Journal of Agronomy. 54(3): 267271.

Yadav, S. K., Y. Singh, R. P. Kumar, M. K. Yadav, K. Singh. 2013. Effect of organic nitrogen sources on yield quality and nutrient uptake of rice (Oryza sativa) under different cropping system. International Journal of Plant Research. 26(1): 58-66.

Yahya, A. J., A. 1., S. K. Azawi, 1989. Occurrence of phosphate solubilizing bacteria in some Iraqi soils. Plant and Soil. (117):135-141.

\section{How to cite this article:}

Bijay Biswakarma, Hemkalyan Verma and Sarkar, N.C. 2018. Effect of Phosphate Solubilizing Bacteria on Yield of Transplanted Rice under Lateritic Belt of West Bengal, India. Int.J.Curr.Microbiol.App.Sci. 7(02): 3192-3204. doi: https://doi.org/10.20546/ijcmas.2018.702.384 